\title{
MELUSINE AS ALCHEMICAL SIREN IN ANDRÉ BRETON'S ARCANE 17 (1945)
}

[Received February 28th 2018; accepted May 8th 2018 - DOI: 10.21463/shima.12.2.o6]

\section{Alex Woodcock}

<alexwoodcock125@gmail.com>

\begin{abstract}
In 1941 the founder of the Surrealist art movement, André Breton (1896-1966), fled from France to New York. Here he met the artist Elisa Bindhoff (1906-200o) who would become his third wife. In the summer of 1944 they stayed on the Gaspé Peninsula in northeast Canada and during their three months there Breton wrote Arcane 17, an extended prose poem named after the 17th card - The Star - in the tarot's Major Arcana. The work combined the personal with the mythical and reflected upon themes of love, loss and war, pertinent for Breton, who, like his new wife, had recently experienced profound personal misfortune. The Star symbolised hope and renewal. By associating this card with the medieval figure of the faery-siren Mélusine, Breton found an image through which he could channel his thoughts about everything from alchemy and politics to the future of humanity. In this article I explore why a 14th Century legend re-emerged in the 2oth and what it offered to a broken man in the midst of global war.
\end{abstract}

KEYWORDS: Surrealism; André Breton, Melusine, Tarot, Rocher Percé/Percé Rock

Introduction

Among the many adventurous paths taken by the Surrealist art movement in the 2oth Century, one of the lesser known but no less fascinating was the moment when it collided with a 14th century legend of a shape-shifting siren. The bridge across six centuries was a book called Arcane 17 (1945), later published in English as Arcanum 17, written by the movement's principal theorist and founder, André Breton (1896-1966). Thematically, Arcane 17 considered loss, redemption, and love. The winged mermaid-serpent, Melusine, hovered over these, lending her presence to Breton's pen as he struggled to make sense of the brutality of war, personal relationships and the cycles of nature. What did he find in her mythology that caught fire in his mind, that seemed relevant? How did a legend dating from the 1390 s end up being central to a book published in the 1940s? I suggest that Arcane 17 was less a retreat from the present than a creative engagement with the past with the intention of laying the foundations for a new future. The engine at the heart of this process was Breton's profound interest in and knowledge of alchemy, articulated through the tarot but rooted in the very bones of the landscape: rocks, stones and crystals.

Arcane 17 was written in a few months of relative calm following some testing circumstances in the author's life. First, Breton was in exile from his native France. At the outbreak of the Second World War he had joined the medical corps of the French Army, as he had done in First World War, but in 1941 he reluctantly left for America due to the increasingly hostile political climate under the Vichy government and the occupying Nazi forces. His reluctance to learn and speak English meant that he only spoke to other francophone expatriates, a situation that "further contributed to his muted isolation - a very new experience for someone who had previously reacted immediately and vocally to current affairs in France" (Clouston, 2017: 15). Second, his marriage to the artist Jacqueline Lamba was disintegrating.

Shima <www.shimajournal.org> ISSN: 1834-6057 
In the autumn of 1942 she left him for the artist David Hare and they separated the following year, with Breton losing custody of their young daughter, Aube. In a foreign land, feeling unable to communicate properly and cut off from his family, it is perhaps unsurprising that he retreated inwards and it is during these years of exile that Breton demonstrated a pronounced shift towards occultism in his work (Clouston, 2017). Against this backdrop of geographic and personal displacement he met the acclaimed pianist, Elisa Bindoff while dining at a Manhattan restaurant with the artist Marcel Duchamp (Morris, 2017: 28). In Arcane 17 he would write of this meeting as an "extraordinary rescue" orchestrated by fate:

\begin{abstract}
A large part of the globe was nothing more than a display of ruins. For myself, I had to really acknowledge, without resigning myself to it, that all I had taken for indestructible in the realm of feeling had been swept away without my even knowing what gust did it: the only sign left was a child to whom, prey to the most justifiable fear, you may have heard me speak long ago (Breton, 1994: 69).
\end{abstract}

Bindhoff too had suffered. Recently divorced from the Chilean politician Benjamin Claro, she had lost her only daughter in a drowning accident off the coast of Massachusetts in 1943. Before they married, in August 1945, Bindhoff and Breton travelled to the Gaspé Peninsula on the north coast of Canada. It was here, between August and October 1944, in a rented cabin near a striking and sheer limestone bluff in Percé Bay called Rocher Percé or Percé Rock, that he wrote Arcane 17. It is an unusual, hybrid text that eschews "any form of linear narrative" and in which Breton "plays in the twilit land between dream and waking", blending the genres of "a love poem, travel journal and political pamphlet... interwoven with alchemical metaphors and discursive references to a range of mythological narratives" (Guérard, 1945: 367; Bauduin, Ferentinou and Zamani, 2018: 24-25). Its very form suggests disjuncture and commonplace calamity, a reflection of his recent lived experience.

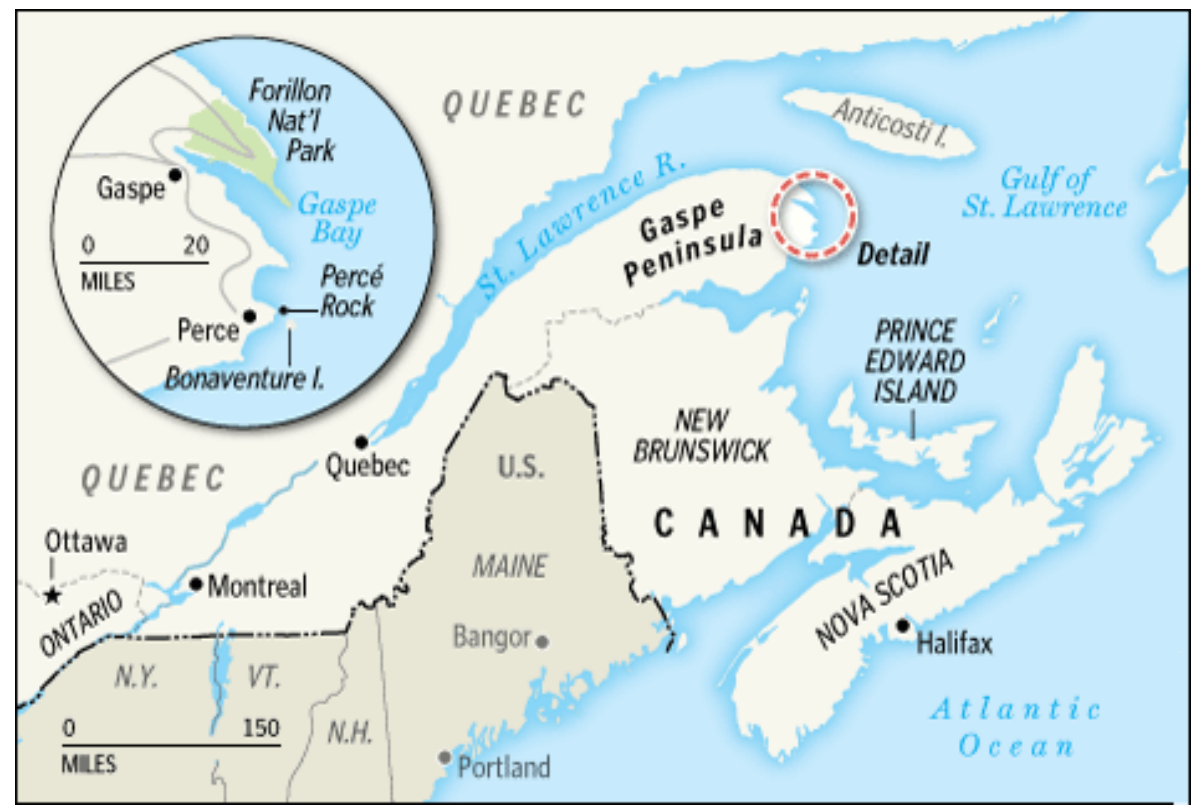

Figure 1 Map of Percé Rock and the Gaspé Peninsula (Ed Pitts, 2010).

\author{
Shima Volume 12 Number 22017 \\ -38 -
}


Writing each morning and exploring the coast with Elisa in the afternoon, Breton became acutely aware of how the rhythms of nature and the long cycles of geology underpinned daily life, where in "everything one treads on, there is something that comes from so much farther back than mankind and which is also going so much farther" (Breton, 1994: 43). In his text this ancient, living landscape flashes with the lightning strikes of the tarot, in particular the 17th card of the major arcana after which it is named - The Star - with its themes of redemption and spiritual renewal and with which he connected the romance of the medieval siren, Melusine.

\section{Melusina After the Scream}

Jean d'Arras finished Le Roman de Mélusine ou L'Histoire de Lusignan for his patron, the Duke of Berry, in 1393. A few years later, in 1405, there appeared a second version, closely resembling it in content but composed in verse, written by Coudrette, for Jean Larchevêque, lord of Parthenay. The story was rapidly disseminated throughout France, Spain, Germany, England and Eastern Europe, with its first printing produced in Germany in 1474 - a prose translation of Coudrette's version by Thüring von Ringoltingen. In Spain, translations of the Jean d'Arras version were published in 1498 and 1526. Multiple editions appeared in the centuries to come. By the standards of the Middle Ages, the work and its variants was a bestseller (Mosley, 2012: 1). The title suggests a text that combines both fiction and history:

Melusine, as the late fourteenth-century reader might well have recognised, is a name associated in myth and folklore with a supernatural female creature, hence setting our expectations that a fairy tale of sorts is to ensue. On the other hand, its second component, Noble History, suggests that we are to read a history of both the feudal domain of Lusignan and one of medieval Europe's foremost families (Maddox and Sturm-Maddox, 2012: 1).

Indeed, the work does not disappoint in this regard. Genres are blended with skill, the romance drawing upon literary sources, folktales and oral histories (Mosley, 2012: 1-3). If the text is hybrid then so is its subject matter. Melusine is herself the result of a union between a human father and a faery mother, as well as the founder of Lusignan, and her presence right at the beginning of the work casts an otherworldly glow over everything that follows. This kind of quasi-supernatural genealogy was not uncommon in the later medieval period among wealthy families. In order to bolster the lineages "of a monarchical or nobiliary dynasty", write Donald Maddox and Sara Sturm-Maddox, they "were often traced back to an exalted, sometimes legendary ancestor, such as a descendant from the Carolingians or even a hero from ancient Troy" (2012:3). The success of the text lies in its basic message - that the seat of the powerful Lusignan dynasty in Poitou was founded by a faery. Yet Melusine is no regular enchantress: as a daughter of a King of Scotland and the faery Presine she has a distinctly royal as well as a supernatural lineage.

Melusine is introduced by way of her mother, from whom she derives her gifts (as well as her curse). The connection with water that is central to the Melusine story might count among the former and is evident when Presine meets King Elinas of Scotland, who will become her father:

One day, after the death of his wife, he was hunting near the coast, in a forest where there was a very lovely fountain. Suddenly he felt a great thirst, and made his way toward the fountain. Approaching it, he heard such melodious singing

\section{Shima Volume 12 Number 22017}


that he believed it must be an angel's voice, and then realized from the dulcet sound that it was that of a woman. He dismounted stealthily, tied his horse to a branch, and edged toward the fountain under cover of the foliage. As he drew near, he beheld the most beautiful woman he had ever seen. He stopped, utterly in awe of this lady who continued to sing more sweetly than any siren, fairy, or nymph (Maddox and Sturm-Maddox, 2012: 22).

Elinas, absorbed by Presine's "music and her loveliness that he knew not whether it was day or night, or whether he was awake or sleeping", asks her to marry him (ibid). She accepts, but with a warning: that if they are to have children together he must never see her in her childbed. This promise is broken, however, and Presine and her three daughters by him Melusine, Melior and Palestine - leave the family home. When she is fifteen, the eldest, Melusine, in a misguided attempt to seek vengeance for her mother, uses her powers to imprison her father inside a mountain. This leaves Presine heartbroken and she curses her daughter for her actions: Melusine is condemned to transform into a serpent from the waist down every Saturday.

The backstory then is set and the action begins again, in a different place (the Ardennes region of France) but within the realms of a familiar situation. While out hunting in the forest, Raymondin, Lord of Forez in Poitou, accidentally fatally wounds his uncle while trying to save him from being gouged by a wild boar. In a state of grief and despondency he rides on through the forest, where at midnight:

he came upon a fountain known as the Fountain of Thirst, which some call the Enchanted Fountain because of myriad adventures that had been occurring there for a long time. The site was striking: a deep ravine flanked by steep cliffs opening onto a moonlit prairie extending through a valley beyond the edge of the forest. The moon shone clear. Raymondin's horse ambled at its own pleasure, unaware of its master's great sorrow, and even of whether he was awake or asleep. As it came at last to the fountain, three ladies were amusing themselves nearby, one the mistress of the other two. (Maddox and Sturm-Maddox, 2012: 31-32).

The latter is Melusine. The discovery of her by a water source in a forest and beneath a full moon is a clear indication to the reader of her supernatural connections, setting up the expectation of what will follow later on. Raymondin, so taken by her beauty and her amiable manners, falls in love, and Melusine agrees to marry him but with one condition: that he make no attempt to see her on Saturday, when she will go into seclusion.

Melusine transforms the fortunes of the impoverished Raymondin and the region of Poitou. Forests are cleared and crops planted; castles and other fortresses are built, fountains and springs nourish the land (Kelly, 1996). This all happens with great speed and seemingly little effort. The fertility of the land is matched by her own. She bears Raymondin ten sons, some of whom have supernormal powers themselves, while others are marked with strange deformities due to their mixed heritage (Spiegel, 1996: 108). Such wondrous events and regular largesse - during their wedding ceremony, for example, Melusine "proferred so many gifts, to both the high and the humble among her guests, that... there was general wonderment about the source of such overwhelming wealth" (Maddox and Sturm-Maddox, 2012: 45) which, in time, begins to arouse suspicion, particularly in conjunction with her mysterious Saturdays. After seven years Raymondin breaks his vow. He spies on Melusine in her chamber and sees her bathing, the lower part of her body transformed into a serpentine tail. It is only when he reveals his discovery to others, however, that Melusine utters "a very

Shima Volume 12 Number 22017

-40 - 
doleful cry and then a heavy sigh" before leaping "from the window into the void" and metamorphosing into "a massive dragon some fifteen feet in length" (ibid: 194) (Figure 2).
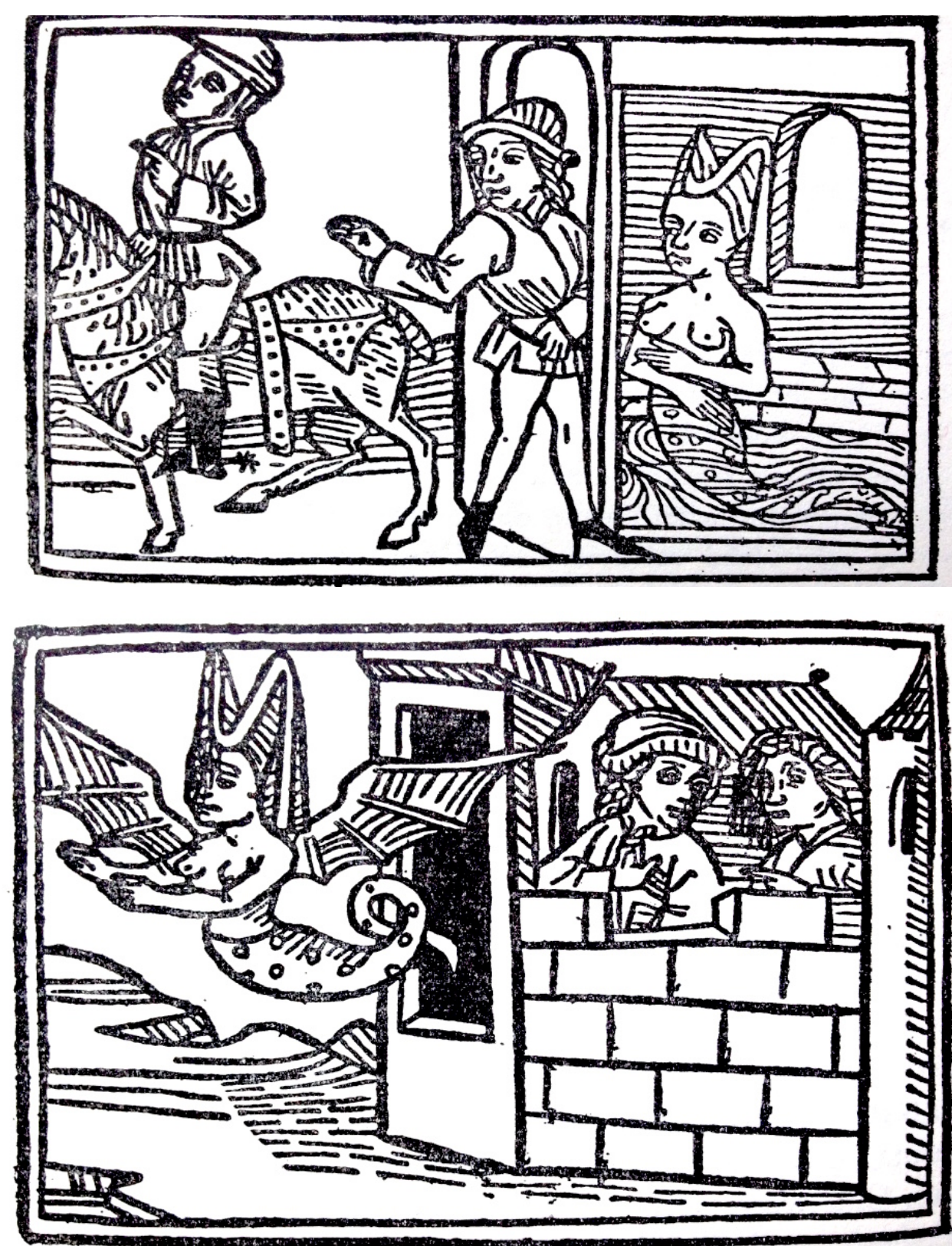

Figure 2. Top: Mélusine in her bath. Below: her flight, in full dragon form. (Illustrations from Von Ringoltingen's late medieval version of the legend - 1979: 71, 92). 
Strictly speaking, in Jean d'Arras's text Melusine is a kind of draconopede, a shapeshifting and partially human dragon rather than a mermaid, and it is in this guise that she appears in early illustrations (Flores, 2000; Mosley, 2012). However, different elements of the story connect strongly with older narratives and Melusine shares numerous traits with many snake women or female monsters from antiquity such as Lamia, Echidne, or the Sirens. The latter are particularly relevant here. Originally, in classical art and culture, they were part-woman and part-bird, but over time the avian characteristics became replaced with piscine ones, until, by the early medieval period, the sirens were fish-women or mermaids (Woodcock, 2005: 102; Woodcock, 2007). The characteristics of the siren that most alarmed medieval writers and theologians were emphasised throughout the period. Thus, her original role as a carrier of the soul from death to new life and her song the irresistible yet deadly call, became associated more generally with temptation, flattery and pride (Benwell and Waugh, 1961; Twycross, 1972; Houwen, 1997). Both Melusine and her mother Presine share siren-like traits, including a connection with water as well as mesmerising singing. The song of the siren is a call to a new life, a new life that involves a death or substantial change of some kind, and is a crucial aspect of siren folklore from Homer's Odyssey to the Mermaid of Zennor (Leach, 2006; Holford-Strevens, 2006; Woodcock, 2016). It isn't difficult to see Melusine in a similar role to these ancient "divinités de la mort, maîtresses des eaux et de la fécondité" (ClierColumbani, 1991: 93). The very first appearance of Mélusine with a piscine tail "occurs in one of Coudrette's earliest manuscripts - here Melusine nurses one of her two youngest children to whom she has returned after her flight from Lusignan" (Mosley, 2012: 76-77). This strand of imagery is likely to be due to the ongoing influence of legends in which mermaids nursed future heroes, their milk affording them extraordinary abilities.

If Melusine is an honorary siren, then, through her connections with them, she also inherits some of their imagery. Of particular importance here is that she is associated with the Roman goddess Venus, herself sometimes depicted with mermaid attendants in ancient art (Grigson, 1978). Venus was a considerable influence on the imagery of mermaids in 12th Century sculpture (Clier-Columbani, 1991: 104; Daoudal, 2007) and during the later medieval period mermaids were frequently depicted holding her attributes of mirror and comb (Figure 3). In medieval culture these were ambiguous symbols, for the most part interpreted as manifestations of vanity but also items that marked the mermaid out as a dangerous supernatural entity, sister to the banshee or the harpy (Lysaght, 1986; Pearson, 2009). In Jean d'Arras's text Melusine, in her bath, holds a comb. However, artists:

frequently added the mirror reminiscent of Venus and mermaids, associated with their seductive vanity, and at times, in spite of his textual description of her as half-serpent, the artists chose to represent her with a fish's tail, thus transforming her into a mermaid (Mosley, 2012: 76).

At some point the twin-tailed mermaid, a favourite among the medieval architectural sculpture of churches and cathedrals on the European mainland (Leclercq-Kadaner, 1997), became known as a 'Melusine', and this version lives on today in corporate logos, such as that for the Starbucks coffee chain. This ambiguity of illustrations in which Melusine is both serpent/dragon and mermaid/siren is perhaps suited to her shapeshifting character, but it also suggests that medieval audiences were willing to understand her in either form. In a way, this expands upon the original text, bringing the older narratives and understandings of sirens and similar female-shapeshifters to the story.

Shima Volume 12 Number 22017

-42 - 


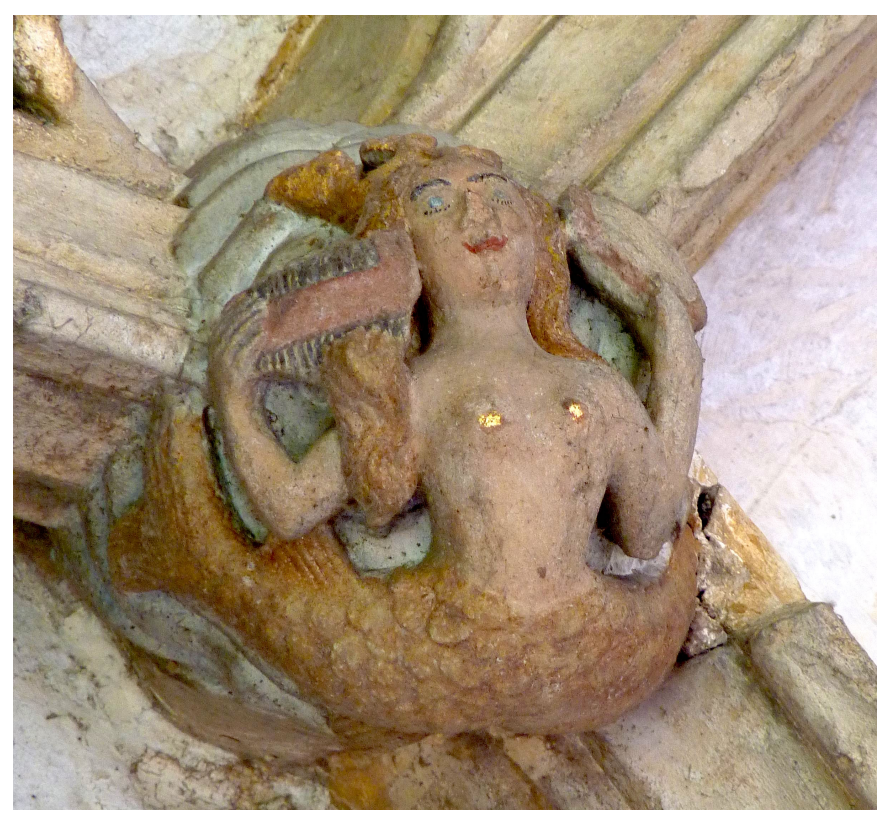

Figure 3 - Example of a late medieval twin-tailed mermaid holding a mirror and a comb at Canterbury Cathedral, Kent, England.

The Crystal, the Butterfly and the Rose

The tarot connects Breton to the Melusine legend in Arcane 17, in particular, the 17th card of the major arcana (after which the book is named): The Star. The Tarot consists of two sets of cards, the major and the minor arcana. There are twenty-two cards in the former and fiftysix in the latter. The minor arcana is divided into four suits much like playing cards (swords, cups, coins, wands) each consisting of ten numbered cards and four picture cards (page, knight, queen, king) though since the 19th Century revival of occultism, which saw a new interest in the tarot, all the cards commonly bear designs. Details of the major arcana images may change from pack to pack (Breton used the version designed by Oswald Wirth in 1927) but the overall imagery remains similar. The Star depicts a naked woman pouring water from two large urns, one emptying into a pool, the other onto land. She appears beneath a sky of stars of which one, positioned centrally and larger than the others, usually with eight points, shines the brightest. In the background are crucial details. In the Marseilles-type decks (discussed below) these include a bird on a tree or bush; on the Wirth deck that Breton used, instead of a bird there is a butterfly on a red rose (Figure 4 ).

Early tarot cards appeared in Northern Italy in the 1370s, as playing cards rather than the exclusively divinatory ones by which they are known now. By the 17th Century, production of the cards had shifted to France, specifically Paris and Lyon, where the card engravers produced decks based upon what became known as the 'Marseilles' pattern. In the 19th Century the tarot was overhauled entirely by scholar and esotericist Arthur Edward Waite and the artist Pamela Coleman Smith. This version, known as the Rider-Waite pack, is perhaps the best-known variant of them all, though there are numerous tarots now available and plenty designed by artists (particularly those with an interest in Surrealism - Ithell Colquhoun and Salvador Dali both made their own versions, for example).

Shima Volume 12 Number 22017

$-43-$ 


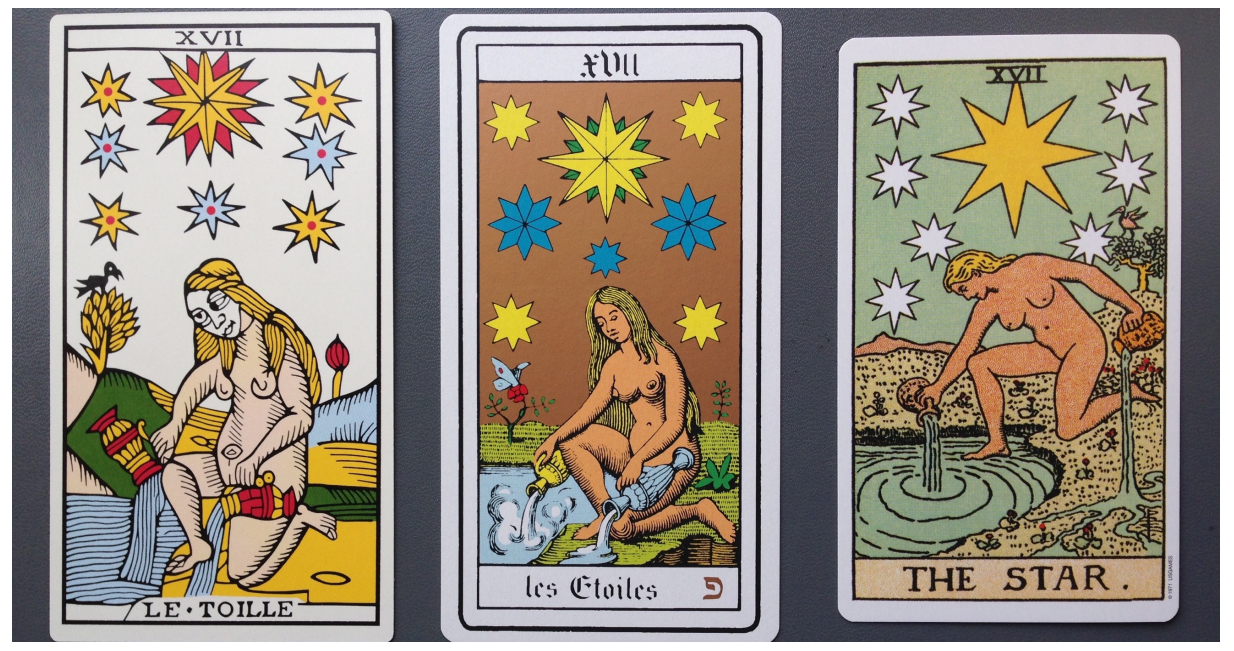

Figure 4 - Card \# 17 - The Star - from various tarot decks. From left to right these are from: a Marseilles-style deck (Jean Dodal), an early 18th Century variant of the Oswald Wirth deck (note the butterfly and rose in the background); and the Rider-Waite deck.

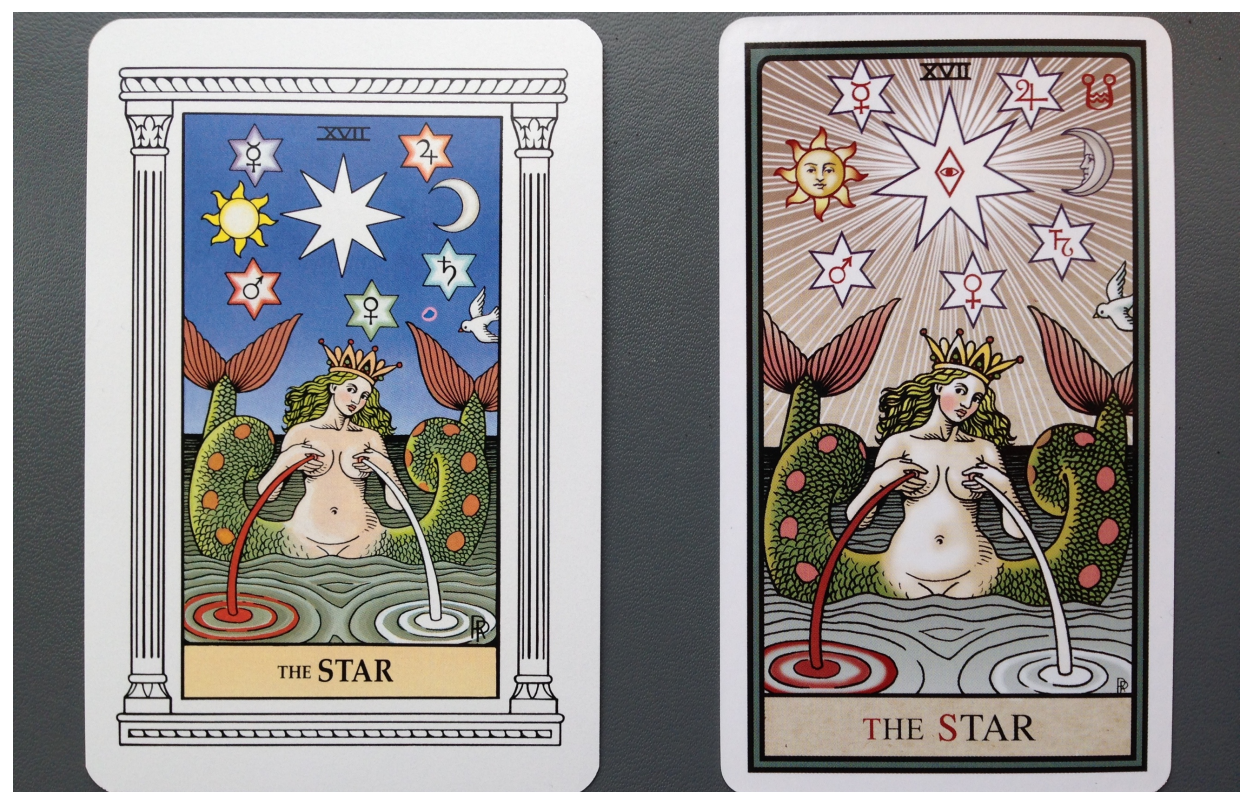

Figure 5 - The star card in Robert Place's Alchemical Tarot (1995). Left, the first edition from 1995; right the fourth edition from 2015, Mélusine as alchemical mermaid.

Again, Venus is closely associated and because of this connection, so are mermaids. Contemporary decks, such as those by Robert Place (1995), make the link explicit. In his Alchemical Tarot the mysterious water-pourer of the star card is replaced with a twin-tailed mermaid (Figure 5). However, there is a shared symbolism that can be traced back centuries

\section{Shima Volume 12 Number 22017}


- long before the production of the cards themselves. This pivots around the association of the evening star (the planet Venus), itself often depicted with eight points, with goddesses of love and fecundity such as the Sumerian Ishtar, the Greek Aphrodite, and of course the Roman Venus (the rose, a Venusian attribute, on the Wirth star card is a further link). This liminal aspect of the mermaid finds a natural home in the Star, itself a card that speaks of superlunary powers manifesting in the physical world, the medium of transmission being both water and a (mythical and/or real, Melusine/Elisa) woman. The card then is a bridge between the material, emotional world and that of the soul, a connector to the depths but also to the future and the promise of new beginnings. But it is also much more than that. Card 17 allowed Breton to access the energy of the past as embodied in the Melusine legend, potentially releasing it into the present and future, a truly radical aspect of his work that deserves some further exploration.

Much of Breton's alchemical thinking had strong geological underpinnings. Indeed, it has been noted that "a geological structure had long sat at the centre of his thought", helping to direct Breton's explorations into alchemy over several decades (Atkins, 2016: online). Of particular relevance is his understanding of crystals. For Breton, there could be "no higher artistic teaching than that of the crystal" (1987: 11). It is perhaps the most apt expression of his term "fixed-explosive" (coined alongside "veiled-erotic" and "magic-circumstantial" as one of his three concepts of "convulsive beauty") (1987: 19) due to its pairing of movement and stasis, in which "the energy of the geological processes that have formed it come to betray the silent, ice-like repose of something frozen in time" (Atkin, 2016: online). As such, the crystal represents both movement and stillness, past and present, form and non-form in one. It is, as Breton noted, "nonperfectible by definition" and conceivably for such reasons (referring to an accompanying photograph by Brassai) he wrote that the "house where I live, my life, what I write: I dream that all that might appear from far off like these cubes of rock salt might appear close-up" (1987: 11). The crystal, then, in its integration of oppositions, is the aim of both artist and alchemist. As Breton had expressed in the Second Manifesto of Surrealism:

Everything tends to make us believe that there exists a point of the mind at which life and death, the real and the imagined, past and future, the communicable and the incommunicable, high and low, cease to be perceived as contradictions. Now, search as one may one will never find any other motivating force in the activities of the Surrealists than the hope of finding and fixing this point (1972: 123-124).

Melusine might be understood as one of these points, herself integrating oppositions in both her legend and her form.

Of particular interest for this discussion is the "fixed-explosive" loosening of the boundaries between past and present. To some degree Breton's thinking about crystals can be illuminated further by the work of the philosopher Gilles Deleuze (1925-1995) and his idea of the "crystal-image", developed through his work on film. In Cinema II (1989) Deleuze drew a distinction between the artificial time imposed by clocks (a way of spatialising time, each moment a self-contained entity) which stands in contrast to lived time, time that flows and in which the past and the future seep into the present in the form of memory and desire. Deleuze suggested that the present might be understood better as a dynamic interpenetration of pasts and futures, or as a perpetual collision and intermingling of the actual (the present moment) and the virtual (a memory or the idea of an object, for example). The virtual, a fragment of time in its purest form, might be glimpsed in what he called

Shima Volume 12 Number 22017 
"crystal-images", found wherever the linear flow of time was disrupted or short-circuited, for example, in cinematic sequences of "mirroring" (ibid). In these, notions of before and after start to break down. As he wrote, "the past does not follow the present that it is no longer, it coexists with the present it was. The present is the actual image, and its contemporaneous past is the virtual image, the image in a mirror" (1989: 79).

The value of this for understanding Breton's Melusinian project is twofold. First, the past is not something spent and inaccessible. Second, the virtual has an energy. If, as Deleuze suggested, we understand it as not merely the past anymore but, in a more expansive manner, as a non-actual dimension always on the verge of actualising itself, then virtuality can be conceived of "as an energy that precedes every actual entity, a truly metaphysical force that continues to guide the evolution of reality, actualizing itself in multiple ways" (Piatti, 2016: 53). In this respect card 17 might be read as a crystal-image, a short-circuit or disruptor of linear time, and Breton's engagement with it a means of allowing him access to an experiential multidimensionality. In this way, the Melusinian energies it contains might be released through his work, and, once active in the world again, help guide the path of humanity along fruitful paths. If, at the heart of Arcane 17 is, as other writers have explored, a concern with alchemy (Schoenfeld, 1984) this concerns not so much its goals as with its processes. Arcane 17 was not a book about alchemy; it was alchemy.

We can see an aspect of this in Breton's creative engagement with the Star card. In a state of lucid thought and receptivity he enters the image, leading him to some wandering meditations as well as some profound conclusions. Breton's encounters with the butterfly and the rose are particularly illuminating, for both reveal invisible processes at work in daily life that only a poetic language can come close to approaching:

The rose says that the ability to regenerate is limitless, it shows that winter, with all its stains and severity, can never be considered more than transitory ... Yes, the highest thoughts, the greatest sentiments can undergo a collective decline and the human heart can also break and books can age and all things must, on the outside, die, but a power that is not at all supernatural makes death itself the basis for renewal. To begin with, it guarantees all the exchanges which make sure that nothing precious is lost internally and that, through its obscure metamorphoses from season to season, the butterfly again puts on its exalted colours (1994: 77-78)

This insight alone, however, is not enough. Breton wants to enter this invisible realm that is revealed by physical things and communicate directly with the presiding "genies":

Still it's here that I invoke you because I'm aware that I can do no more till you appear, genies who secretly preside over this alchemy, you masters of the poetic life of things. This life is beyond the life of beings and very few are capable of understanding its reality, much less living it, although it constantly intrudes upon the other. That other is made to be ground down, it is terribly exposed and fragile: it also happens that entire sections crack from it and that is never so true and when one loses without warning what one cherishes most in the world ... In this state of instantaneous and total wreckage, it still rests on you, genies, to reach this heart, and without any of it transpiring outside or for its own sake, to get your alembics working on it. And if the operation you begin requires days and is paid for with the prism of tears, nevertheless the conjuring

\author{
Shima Volume 12 Number 22017 \\ -46 -
}


does still take place and life does end up, if not with a re-entry into grace, at least by being tolerable again (ibid: 78-79).

Ultimately, Elisa/Melusine in her siren aspect is the guide through this darkness, from death to new life, the alchemical mermaid integrating oppositions and through this, allowing her energies to infiltrate the present. The Star card is both access point and map, a means of illuminating the emotional landscape and providing a way by which Breton's poeticallyinclined sensibility might yet find meaning in the destruction and personal upheaval of the times, emerging renewed. This re-enchantment of a world gone sour draws upon the abstract realms of myth and occultism but it takes root in the physical world. There is a moment when Breton breaks his active meditations. "A gap in the dream", he notes, "Are we saying that nothing is ever found again?" (1994: 84). But in many respects, he had already found it, in writing Arcane 17, in his relationship with Elisa, and in the landscape around the immense Percé Rock on the coast of Quebec.

\section{The Luxurious Drifting of Aquatic Birds}

From its inception, Surrealism had taken an interest in nature, linking it to the marvelous, which had led some to compare the movement to Romanticism (Aubert, 2011). Breton, however, while acknowledging a debt was nevertheless keen to distinguish the Surrealist project from that of the Romantics. For him, the wild places allowed a greater engagement with material reality rather than an escape from it. While Arcane 17 might appear, at first, to fall into the latter category - it is, after all, named after a tarot card - its subtle tracings of myths and symbolism work to root both firmly in the landscape. Breton's occultism is, after all, an applied one. As he had demonstrated, via the figure of Melusine, the supernatural lived at the heart of the everyday, something that his poetic reading of card 17 iterated through its imagery of real things pointing towards invisible processes. Integrating these observations into his daily life on the coast of Quebec, Breton repurposes the great work of alchemy as the ordinary and humble, where the transformative potential of the silent, daily mysteries of the natural world are revealed as both wondrous and accessible.

Rocher Percé/Percé Rock (also known locally as Pierced Island) is a sheer rock formation in the Gulf of St Lawrence off the tip of Quebec's Gaspé Peninsula (Figure 6). This substantial 'pierced rock' (its name due to a natural arch over fifteen metres high on its southern end) is nonetheless a shapeshifter, disappearing entirely from view in coastal mists and prey to erosion that will eventually wear it down completely (Breton estimated that it would take 13,000 years - 1994: 52). These processes of change and disintegration, in something so monumental and apparently timeless, moved Breton enormously. "It's beautiful", he wrote, "that its longevity is not limitless and at the same time that it covers such a succession of human lives" (1994: 52). Beautiful too, that the stones that are weathered out of it, falling into the sea and worn smooth by the tides, becoming glistening agate pebbles, should inspire so much wonder. "Geologists and palaeontologists reach new peaks of pleasure all over the Gaspé Peninsula" he noted, "where they calculate the immemorial landslides, of which a pebble dressed as a harlequin, uniformly polished by the sea, sometimes gives solitary testimony" (1994: 43). The fragments, easy to pick up and delightful to collect, speak of the whole. 


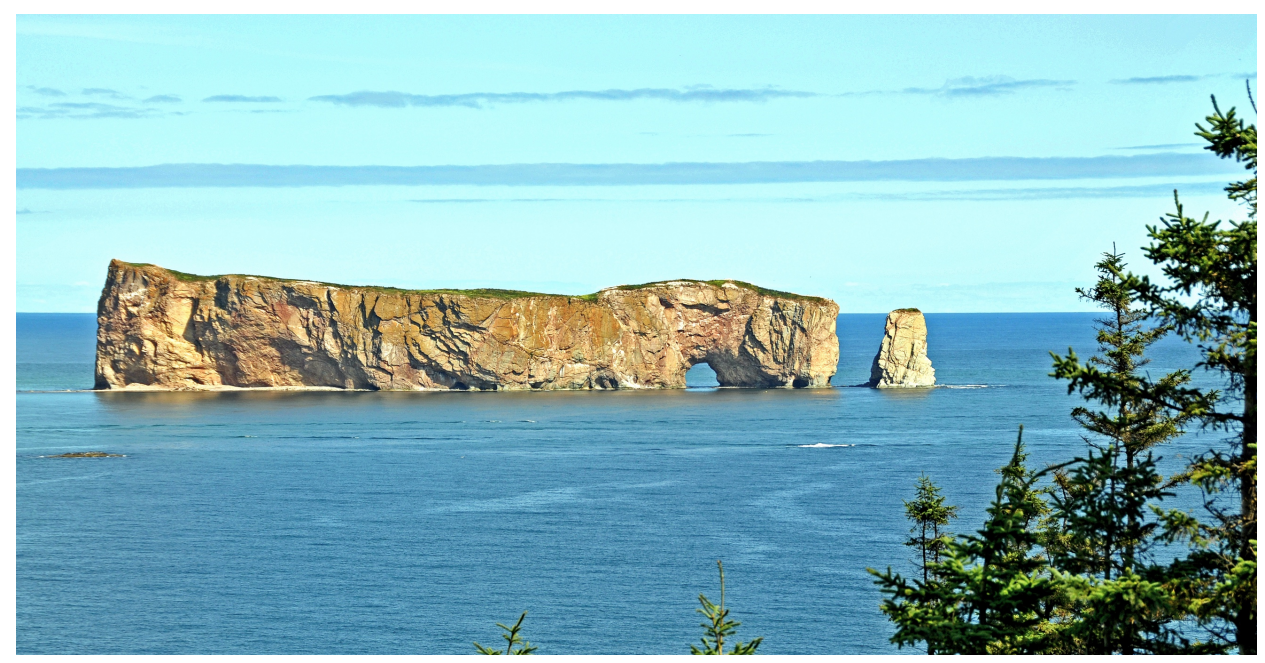

Figure 6 - Percé Rock/Rocher Percé (photo by Dennis Jarvis, courtesy of Wikimedia Commons:(https://commons.wikimedia.org/wiki/File:Percé_Rock.jpg).

But it was the Melusinian fusion of opposites that really captured Breton's mind - in particular, the organic and the inorganic, as represented by the giant rock and its attendant bird life. On this he wrote eloquently:

The word symphony has been used with regard to the rocky ensemble that dominates Percé, but here was an image which only became powerful from the moment one discovered that the repose of birds was a perfect match for the craggy slopes of those sheer battlements, so that the organic rhythm was perfectly superimposed on the inorganic rhythm, as if it needed to fuse with it in order to hold itself together. Who could have thought of lending the elasticity of wings to an avalanche... It's marvelous that the very folds imprinted on the rock beds by the ages create a trampoline for what is most inviting about life: the soaring, the just-veering-off, and the luxurious drifting of aquatic birds (ibid: 26).

From the rocks to the birds, feather and stone as one. In Breton's hands the geology and natural life of the region was integrated into his own alchemical thinking.

\title{
Conclusion
}

It is perhaps unsurprising that Breton found the Melusine myth appealing. It is a legend throughout which grief runs like an underground stream. King Elinas is distracting himself from the death of his wife by hunting in the forest when he meets Presine; Count Raymondin is similarly overcome, to the point of being in an altered state of consciousness, when he meets Melusine. Breton, of course, was grieving for the departure of his second wife Jacqueline (as well as for numerous other losses, personal and cultural, due to the war) when he met Elisa, and in his own "extraordinary rescue" he saw a reflection of the mythological ones. "Before I met you I'd known misfortune, despair", he writes; when "fate brought you to

\author{
Shima Volume 12 Number 22017 \\ -48 -
}


me, an enormous shadow was in me and I might even say it was inside me that the window opened" (1994:35, 68).

If Breton cast Elisa as his own Melusine then to a certain extent he also cast himself in that role too. Melusine herself is a secret monster in the heart of the court she has largely created, her burden one of self-knowledge. Breton is the Surrealist theorist around which an entire art movement developed. In exile and looking for a way forward, from his personal losses to the global devastation of war, Breton took an increased interest in the occult as well as the everyday rituals of life (Clouston, 2017; Zamani, 2018). This impulse toward the esoteric in no way ruled out "an openness to the simple everyday things" (Caws, 1987: xii): in fact, it is the simple everyday things that are revealed as the saving graces of life. The land itself, the pebbles on the beach, the trees and the clouds all appear as tokens of the same transformational power that lies at the heart of the Melusine story. By connecting the two, Breton infused everything with her presence. "Melusina after the scream", he wrote, "I see her scales mirrored in the autumn sky" (1994: 59).

In Arcane 17 Breton wrote his way out of the fog. His sentences, built upon an intricate framework of medieval legend, contemporary occultism and close observations of nature, facilitated a kind of recovery. Or, as he put it: "One must go to the depths of human sorrow, discover its strange capacities, in order to salute the similarly limitless gift that makes life worth living" (1994: 88). A medieval mermaid had been key to this understanding. Indeed, Melusine in Breton's text offered nothing less than a revelation of the ordinary as extraordinary, a means of grounding a poetics of alchemical thought into the very landscape, and through this, creating a lifeline by which one might survive - even in the darkest times.

\section{BIBLIOGRAPHY}

Alban, G.M.E (2003) Melusine the Serpent Goddess in A. S. Byatt's Possession and in Mythology, New York: Lexington

Atkin, W (2016) 'Crystalline Thought: Alchemy and "Visionary Mineralogy" in the Writings of Andre Breton', Immediations n4 nı:

https://courtauld.ac.uk/research/publications/immediations/immediations-2016-volume4-number-1/article-immediations-2016-volume-4-number-1/will-atkin-immediations-2016 accessed 4th April 2018

Aubert, N (2011) 'Wilderness in André Breton's Arcane 17', Romance Studies n29: 198-208

Balakian, A (1994) 'Introduction' in Breton, A (translated by Balakian, A) Arcanum 17, Los Angeles: Sun and Moon Press: 7-16

Bauduin, T (2014) Surrealism and the Occult: Occultism and Western Esotericism in the Work of André Breton, Amsterdam: Amsterdam University Press

Bauduin, T, Ferentinou, V and Zamani, D (2018) 'Introduction: In Search of the Marvellous' in Bauduin, T, Ferentinou, V and Zamani, D (eds) Surrealism, Occultism and Politics: In Search of the Marvellous, London: Routledge, 24-45

Benwell, G and Waugh, A (1961) Sea Enchantress: The Tale of the Mermaid and Her Kin, London: Hutchinson

\section{Shima Volume 12 Number 22017}

-49 - 


\section{Woodcock: Melusine in Breton's Arcane 17}

Breton, A (1972) 'Second Manifesto' in Breton A (translated by Lane, H.R and Seaver, R) Manifestoes of Surrealism, Ann Arbor: University of Michigan Press: 174-178

----- (1987) Mad Love (translated by Caws, M.A) Lincoln: University of Nebraska Press

----- (1994) Arcanum 17 (translated by Rogow, Z), Los Angeles: Sun and Moon Press

----- (2008) Arcane 17 (Béhar, H [ed]) Paris: Biro Éditeur

Caws, M.A (1987) 'Translator's Introduction' in Breton, A (translated by Caws, M.A) Mad Love, Lincoln: University of Nebraska Press: ix-xvii

Clier-Colombani, F (1991) La Fée Mélusine au Moyen Age: Images, Mythes, Symboles, Paris: Editions Le Léopard d'or

Clouston, V (2017) André Breton in Exile: The Poetics of 'Occultation', 1941-1947, London: Routledge

d'Arras, J (2012) Melusine; or the Noble History of Lusignan (translated by Maddox, D and Sturm-Maddox, S) University Park: Pennsylvania State University Press

Deleuze, G (1989) Cinema II: The Time-Image (translated by Tomlinson, H and Gaketa, R), London: Athlone Press

Daoudal, S (2007) Sirènes Romanes en Poitou (XI - XII siècles): Avatars Sculptés d'une Figure Mythique, Rennes: Presses Universitaires de Rennes

Flores, N.C (200o) 'Effigies Amicitiae ... Veritas Inimicitiae: Antifeminism in the Iconography of the Woman-Headed Serpent in Medieval and Renaissance Art and Literature' in Flores, N.C (ed) Animals in the Middle Ages: A Book of Essays, London: Routledge: 167-195

Grigson, G (1978) The Goddess of Love: The Birth, Triumph, Death and Rebirth of Aphrodite, London: Quartet

Guérard, A (1945) Review of Arcane 17, Books Abroad n19: 366-367

Holford-Strevens, L (2006) 'Sirens in Antiquity and the Middle Ages', in Austern, L.P and Naroditskaya, I (eds) Music of the Sirens, Bloomington: Indiana University Press: 16-51

Houwen, L.A.J.R (1997) Animals and the Symbolic in Mediaeval Art and Literature, Groningen: Egbert Forsten: 77-92

Kelly, D (1996) 'The Domestication of the Marvelous in the Melusine Romances' in Maddox, D and Sturm-Maddox, S (eds) Melusine of Lusignan: Founding Fiction in Late Medieval France, Athens: University of Georgia Press: 32-47

Leach, E.E (2006) 'The "Little Pipe Sings Sweetly While the Fowler Deceives the Bird": Sirens in the Later Middle Ages', Music and Letters n87: 187-211

\section{Shima Volume 12 Number 22017}

-50 - 
Leclercq-Marx, J (1997) La Sirène dans la Pensée et dans L'Art de L'Antiquité et du Moyen Âge: Du Mythe Païen au Symbole Chrétien, Brussels, Académie Royale de Belgique

Lysaght, P (1986) The Banshee: The Irish Death Messenger, Boulder: Roberts Rhinehart

Maddox, D and Sturm-Maddox, S (eds) (1996) Melusine of Lusignan: Founding Fiction in Late Medieval France, Athens: University of Georgia Press

Morris, D (2017) 'The Context' in Lepetit, P, Richardson, J and Welson, J (2017) André Breton's Arcane 17: A Lodestar for the $21^{\text {st }}$ Century, Rhos-on-sea: Dark Windows Press: 27-29

Mosley, L.N (2012) 'The Role and Meaning of the Melusine Myth in Modern Narrative: A Jungian Perspective', (unpublished) PhD thesis, University of Georgia, Athens

Pearson, T (2009) 'The Mermaid in the Church', in Block, E with Billiet, F, BethmontGallerand, S and Hardwick, P (eds) Profane Images in Marginal Arts of the Middle Ages, Turnhout: Brepols: 105-121

Piatti, G (2016) 'The Life and the Crystal: Paths into the Virtual in Bergson, Simondon and Deleuze', La Deleuziana n3: 51-58

Place, R (1995) The Alchemical Tarot (book and deck), New Castle: Hermes

Rogow, Z (1994) 'Translator's Preface' in Breton, A Arcanum 17, Los Angeles: Sun and Moon Press: $17^{-22}$

Schoenfeld, J.S (1984) 'Andre Bréton: Alchemist', The French Review n57: 493-502

Spiegel, G.M (1996) 'Maternity and Monstrosity: Reproductive Biology in the Roman de Mélusine' in Maddox, D and Sturm-Maddox, S (eds) Melusine of Lusignan: Founding Fiction in Late Medieval France, Athens: University of Georgia Press: 100-124

Twycross, M (1972) The Medieval Anadyomene: A Study in Chaucer's Mythography, Oxford: Blackwell

Von Ringoltingen, T (1979) Die Historie von der Schönen Melusine, Leipzig: Insel-Verlag

Woodcock, A (2005) Liminal Images: Aspects of Medieval Architectural Sculpture in the South of England from the Eleventh to the Sixteenth Centuries, Oxford: John and Erica Hedges

----- (2007). 'Death and the Mermaid: The Carved Capitals at St Michael's, Horwood (North Devon) and their Patrons', Journal of the British Archaeological Association 160: 147-164.

----- (2016) 'The Medieval Mermaid at Zennor' in Wackett, J (ed) All Monsters Great and Small (exhibition guidebook), Truro: Royal Cornwall Museum: 38

Zamani, D (2018) 'Melusina Triumphant: Matriarchy and the Politics of Anti-Fascist Mythmaking in André Breton's Arcane 17 (1945)' in Baudin, T.M, Ferentinou, V and Zamani, D (eds) Surrealism, Occultism and Politics: In Search of the Marvellous, London: Routledge: 95-117

\section{Shima Volume 12 Number 22017}

$-51-$ 